\section{The origins of the Lindsay Society for the History of Dentistry on the occasion of its Golden Jubilee, 6th October 2012}

\author{
J. S. Robson ${ }^{1}$
}

IN BRIEF
Reviews how and why the Lindsay
Society was formed 50 years ago.
Reveals the personalities of the dentists
involved in developing the Society who
all influenced the recording of the history
of the profession.
Explores the relationship between the
Lindsay Society and the BDA, especially
the BDA Museum which has a burgeoning
reputation.

On the special occasion of the society's Golden Jubilee Conference in Cardiff, as a historical institution a short review of its own history was apposite.

\section{ORIGINS}

In 1962 it was decided that there should be a club for the study of the history of dentistry. The prime movers of this project were Mr J. A. Donaldson and $\mathrm{Mr}$ J. E. McAuley, who resolved to name the club the Lindsay Club to honour and perpetuate the memory of Lillian Lindsay CBE, the first female dental graduate in the UK, qualifying with honours at Edinburgh Dental School in 1895. Outside of dentistry, Lindsay was a great historian and also a self taught linguist with an additional interest in literature. She had many academic and personal honours bestowed including being elected the first lady president of the BDA in 1946. Sadly she passed away in 1960, two years before the club was founded. ${ }^{1,2}$

The inaugural meeting was held on 18 October 1962 and thus October 2012 marked the Golden Jubilee of what was then the Lindsay Club but has since been redesignated the Lindsay Society. Why the title changed from 'club' to 'society' is a mystery lost in the passage of time, but was probably one of those things that was considered a good idea at the time. Perhaps the word 'club' has sporting connotations, whereas 'society' has more resonance as a learned organisation.

Chairman, Lindsay Society, Dunelm, Black Dyke Lane, Upper Poppleton, York, Y026 6PJ

Correspondence to: J. Stuart Robson

Email: stuartrobson367@btinternet.com

Accepted 9 November 2012

DOI: 10.1038/sj.bdj.2013.153

${ }^{\circledR}$ British Dental Journal 2013; 214: 123-125
The first office bearers were Chairman, Ronald Cohan, Secretary, J. E. McAulay and Treasurer, A. M. Donaldson, with $\mathrm{Mr}$ Leslie Godden, former editor of the $B D J$ and $\mathrm{Mr}$ Greer Walker, a former president of the BDA, completing the committee. ${ }^{2}$

The club received the approval of the then BDA Council and was a small but nonetheless constituent part of the BDA, although curiously it was associated with, not affiliated to the BDA. Presumably this was to make it independent of BDA finances and therefore had to be self supporting. ${ }^{2}$

\section{CONCEPTION}

It is worth digressing a little at this juncture to look at how and why the Lindsay Club was conceived, which hinges on the elected secretary, Mr McAuley. He had an inherent curiosity in extraneous medical and dental details that led him to seek the origins of anatomical eponyms, that is to say the origins of personal names associated with terms such as Paget's disease or Sjögren's syndrome for example. He wanted to know more about who these men were. Pursuing this interest when he was in Army Dental Corps during World War II, he was passing through London with half a day to spare and called into the BDA at their then head office at 13 Hill Street in London to visit the library. Here he met Lillian Lindsay who at that point was the BDA's librarian. ${ }^{1}$ Later on he was posted to command a Field Dental Unit attached to the Special Forces being gathered by Orde Wingate in Burma, known as the Chindits. Due to the monsoon weather, he again had time to spare and wrote to Mrs Lindsay asking for some reading material about dentistry and allied topics to pursue his curious hobby, which she supplied, thus starting their mutual friendship. After being demobbed his interest in medical and dental history led him to join the Osler Club of London in 1952, although this was mainly medical based. Osler was the Professor of Medicine at Oxford and was elected the first President of the Royal Society of Medicine's History Section, a position that he was succeeded in by Mrs Lindsay. The Osler Club was very successful and led McAuley to wonder about founding a similar body devoted solely to the history of dentistry. ${ }^{3}$

In 1960 he contacted Leslie Godden, then editor of the $B D J$, who in turn suggested that they get Archie Donaldson involved. This triumvirate of McAuley, Godden and Donaldson developed the idea and with enthusiastic input from Ronald Cohan and eventually John Menzies Campbell, had an exploratory meeting in March 1962 when a constitution was drawn up. Membership was limited to members of the BDA, 'other than overseas dentists and others not dentally qualified'.

The first member's meeting was in October 1962 when the guest speaker was Sir Zachary Cope whose address was entitled 'The tomes tradition' and as far as can be ascertained was largely about how dental education for undergraduates had evolved. Thirty members were present at Hill Street to hear this lecture. ${ }^{4}$

Subsequently several members of the Osler Club not only joined the Lindsay 


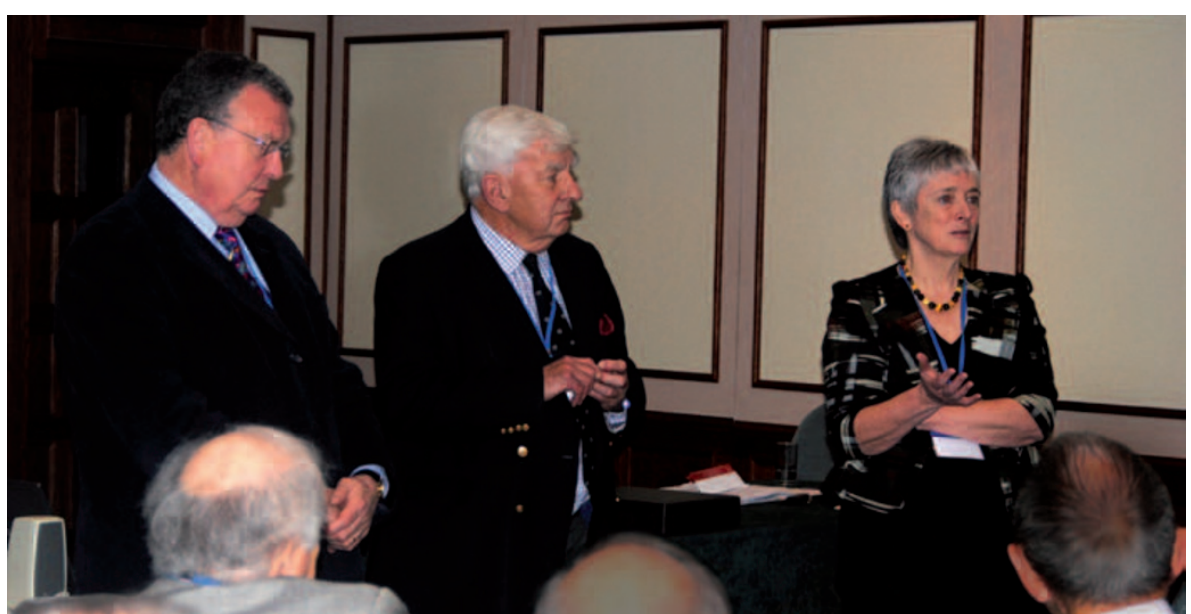

Fig. 1 Dr Stuart Robson, Society Chairman and Professor Nairn Wilson and Dr Margaret Wilson, guest lecturers at the Golden Jubilee meeting, (left to right)

Club, but also presented lectures on diverse subjects such as dental anaesthesia, relationships between dentistry and medicine, history of the theories of tooth decay and dentistry in the armed services. Consequently, at their invitation in 1971 on the 50th anniversary of the Army Dental Corps a joint meeting was held at the RADC headquarters in Aldershot when a history of the RADC Museum was presented by the curator at the time, Staff Sergeant Poole.

\section{HISTORY OVER THE YEARS}

Looking through the history of the society several other curiosities emerge. On one occasion, Ronald Cohan organised a visit to the Vale of Evesham to explore the family history of the man who might be considered to be the great grandfather of the science of dentistry in the UK, Sir John Tomes. They visited St Peters Church at Welford on Avon where Tomes's parents were married and John was baptised in 1815, and then to Weedon where Sir John's first child John, who died aged three in 1848 , lies in a family vault. ${ }^{5}$

Another curiosity was a paper given by McAuley on Paul Revere. Revere was a dentist in Boston, Massachusetts, who was involved in the American War of Independence in 1775 and spawned the well know poem by Longfellow, ${ }^{6}$ beginning 'listen my children and you shall hear, of the midnight ride of Paul Revere, on the eighteenth of April in seventyfive'. He rode from Boston to give early warning about the advancing British army, which resulted in the battles at Concord and Lexington. The curiosity is that Paul Revere's great granddaughter was Lady Grace Osler, wife of Sir William Osler who founded the Osler Club previously mentioned. ${ }^{5}$

Over the years the club, or rather the society as it became known, met each Autumn, usually at attractive venues with some local history ranging from Utrecht, Malta, York, Edinburgh, Winchester, Lancaster, Stirling, Bournemouth, Ironbridge and Dumfries when a successful joint symposium was held with the Henry Noble Research Group based in Glasgow University, to name but a few. Looking to the future, plans are afoot for a joint venture with the Royal Odonto-Chirurgical Society in Edinburgh in 2017.

At this Golden Jubilee time, it is worthwhile to reflect for a few moments on the halfway stage, the Silver Jubilee meeting held in York 25 years ago with a range of delegates aged between 25 and 90. Muriel Cohan who is mentioned above, spoke about Mrs Lindsay, and Mrs Christine Hillam, a long time member and author of The roots of dentistry, ${ }^{7}$ gave an excellent paper about dentistry in York in the 18th century. The meeting was enhanced by a visit to York Minster library to see the original of Charles Allen's book Operator for the teet $h^{8}$ published in 1685, the first dental textbook printed in English. There are also some excellent illustrated manuscripts relating to St Apollonia the patron saint of toothache sufferers, who has since has been adopted to encompass dentistry. ${ }^{5}$

This potted history of the society would not be complete without reference to the journal The Dental Historian. This

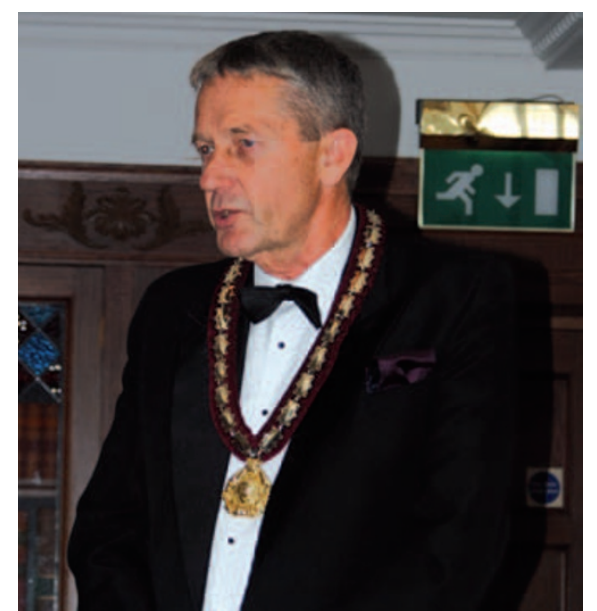

Fig. 2 Mr Frank Holloway, BDA President, guest speaker at the 50th celebration dinner

publication started as a newsletter in $1975^{4}$ and under the guidance of Christine Hillam and Margaret Clennett developed into the booklet published every six months with which we are now familiar and whose circulation is far exceeds membership numbers. Latterly this journal has developed further due to the efforts of Dr Geoff Garnett and Professor Stanley Gelbier for whom the society is most grateful. The other publications attributed to the society are the Advance of the dental profession, ${ }^{4}$ a comprehensive hardback history of the BDA and a booklet about Lillian Lindsay 1871-1960. ${ }^{1}$

\section{THE SOCIETY IN THE 21ST CENTURY AND ON ITS GOLDEN JUBILEE}

Not unnaturally, there has always been a close relationship between the Lindsay Society and the BDA Museum, maybe never more so than currently under the patronage of Museum Director Rachel Bairsto and her colleagues, one of whom, Melanie Parker, frequently contributes to bdanews and presents historical papers at Lindsay conferences. Members of the society have worked over many years as volunteers in the museum, identifying items, aging them, cataloguing them and otherwise supporting the organisation that is among the best small museums in London, attracting many lay visitors and school parties.

The society's good work continues to this day, for example the society provided seed corn funding for the purchase of the portrait by Sir John Lavery in 1929, 'The dentist', which now adorns the BDA 


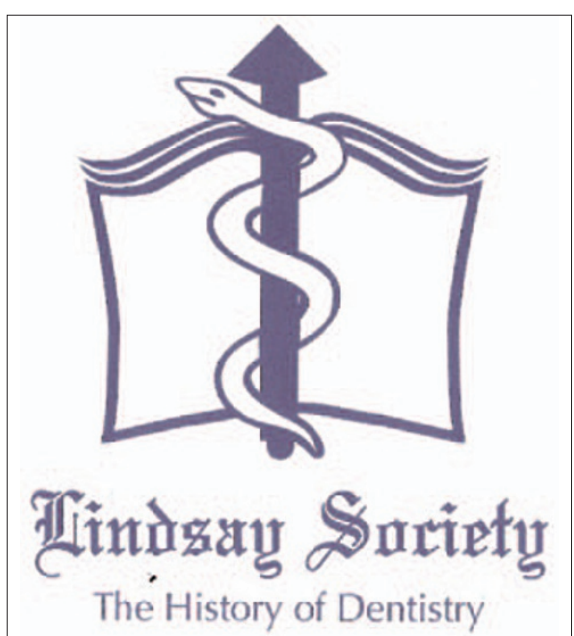

Fig. 3 Newly designed Lindsay Society logo

headquarters in Wimpole Street, London. Other notable achievements include our association with the John McLean Archive project and the increasing success of the Lindsay memorial lecture at the BDA Conference, which has attracted speakers of world renown including Professor Nairn Wilson, former president of the GDC who, together with his wife Margaret, gave a joint presentation on how light has revolutionised dentistry at the Golden Jubilee anniversary conference (Fig. 1). Other speakers at Cardiff included Dr Danielle Huckle on dental general anaesthesia in Wales, the society's new chairman Dr Stuart Geddes, who did a remarkable illustrated talk on dentistry featuring a world wide collection of postage stamps, Melanie Parker on a review of eminent ladies of dentistry at the start of the 20th century and Professor Gelbier who gave a biography of Geoffrey Slack CBE, the father of dental public health. The social part of the conference was exceptional, with a visit to the Welsh National Assembly Building, a visit to the Welsh National Opera 'La Boheme' and a celebratory dinner at which the speakers were the BDA President Dr Frank Holloway (Fig. 2) and the Lindsay Society Chairman, Dr Stuart Robson. After many years it was decided to mark this Golden Jubilee by designing a $\log 0$ (Fig. 3) to enhance the identity of the society. Following several options, a final version illustrating the book of life, reflecting the association between dentistry and medicine, was chosen and designed in the BDA's corporate colour to indicate the close link between the two organisations.

Crucially, as ever, the success or otherwise of a society depends on the enthusiasm of the members who undertake the organisation and administration and apart from all those already mentioned historical appreciation must be accredited to the former secretary Anne Hargreaves, treasurer Dr Peter Frost, the current secretary, Dr Brian Williams and former chairmen Dr John Beal, Dr. John Craig and Professor Robin Basker among many others. ${ }^{2}$

1. Cohen R A. Lilian Lindsay 1871-1960. Br Dent J 1971; 131: 121-122.

2. Minutes of Lindsay Society meetings 1962-2012. (Can be viewed by arrangements with the BDA).

3. Dental historian. Br Dent J 1988; 165: 419.

4. British Dental Association. The advance of the dental profession: a centenary history 1880-1980. London: BDA, 1979.

5. McAuley J E. The foundation of the Lindsay Club. Br Dent J 1988; 164: 90-91.

6. Longfellow H W. Paul Revere's ride. The Atlantic Monthly, 1860.

7. Hillam C. The roots of dentistry. London: The British Dental Journal, 1990

8. Allen C. The operator for the teeth: showing how to preserve the teeth and gums from all the accidents they are subject to. York: John White, 1685. 